\title{
The Effectiveness of Literature Response Journal Writing in Developing English Writing Content And Vocabulary Choice among Secondary School Students
}

\author{
Mohammed Elsharkasy ${ }^{1}$, Prof. Mostafa M. A. Badr ${ }^{2}$ \\ ${ }^{1}$ A M.D Candidate in Tanta University, Secondary School EFL Teacher \\ ${ }^{2}$ Professor of TEFL, Faculty of Education, Tanta University
}

\begin{abstract}
Corresponding author mail:- m_elsharkasy@yahoo.com

The purpose of the present paper was to investigate the effectiveness of literature response journal writing in developing EFL writing content and vocabulary choice among 85 students of the first year secondary school. The quasi-experimental pre-post-test experimental-control group design was adopted by the researcher. The sample for the study was 85 students divided into two groups, 40 students for the experimental group ( 9 male and 31 female students) and 45 for control group (14 male and 31 female students). In order to achieve the purpose of the study and collect data, the researcher developed EFL writing pre-post-test $\mathrm{s}$ and a rubric for scoring them. The findings showed significant differences between the experimental and control group in EFL writing content and vocabulary choice in favor of the experimental group. At the end of the study, the findings reached were interpreted, some implications, suggestions and recommendations were presented and some topics for further research were suggested.
\end{abstract}

Keywords: literature response journal writing, secondary school, EFL writing content, EFL writing vocabulary choice

\section{Introduction}

The ultimate aim of teaching and learning English is to help students communicate effectively. Writing is considered one of the most important skills in English as a foreign/second language to meet the communicative needs. According to [1], writing is "a way of producing language that you do naturally when you speak". He adds that "Writing is a form of communication that takes place on paper or on a computer screen. Writing is also a way of generating and arranging ideas, placing them on paper, revising and editing them, and rewriting them ".

Writing is a complex process which, according to Flynn and [2], enables writers to explore and clarify their thoughts and ideas. Writing promotes critical thinking and learning by encouraging collaboration and allowing time for reflection. When ideas are written down, they can be analysed, reconsidered, added to, rearranged, and changed. Among the basic language skills in the language acquisition process, "competent writing is widely considered as the last language skill to be mastered for both language native speakers and foreign/second language learners" [3]. As [4] states, "writing in English is vital in college, and it will be an asset in your profession". EFL learners' success in English writing benefits them not only in their English language learning but also in their future careers [5],

However, a large number of EFL students find English writing challenging [6] The nature of writing itself is not engaging enough to motivate English learners to practise on a regular basis [7]. Nothing is more disappointing for most EFL students than finishing a writing task and discovering that it will be presented to the teacher, who will see it as a source of errors that must be corrected [8]

Writing is a complex learning and teaching skill, as it requires many other skills to be acquired. Additionally, writing is a skill that needs to be mastered with extra work. Before doing and writing well, students need to gain a lot of knowledge by listening to others, talking to others, and reading more books. They may convey their messages to their readers through writing. They will have to produce a 
text using English to deliver the messages. They must write about what they think in their minds and state it using the appropriate method on a piece of paper [9] Writing requires not only ideas but also vocabulary, syntax, and punctuation in order to explain particular concepts and communicate certain ideas. [10] argues that good writing is more difficult than good speaking. A writer must improve all features of writing in order to master it [11]. [12] Claims that producing a cohesive, fluent, long piece of writing is the most challenging thing in language since the reader must understand what has been written without asking for explanation or relying on the writer's tone of voice or speech.

Therefore, students with low and average competencies in writing face a big challenge when they deal with writing fluency. They are required to write smoothly when the ideas flow through their minds. Although it is recommended that low- and average skill students write freely without caring about spelling and grammar, they nevertheless struggle to communicate their thoughts and feelings owing to a lack of vocabulary, writing practice, and reading [13].

Since writing is a skill, it makes sense that the more you practice writing, the better your writing will be. Keeping a daily or nearly daily journal is a good way to get practise writing even before you start writing essays Calkins [14] believes that giving students additional opportunity to write 'freely and unselfconsciously' can help them improve their writing skills. Consistent writing is one technique to develop their writing skills.

In general, there have been a variety of approaches to teaching writing. However, journal writing is a way that provides students with an opportunity to practise more writing. "Journal writing is a technique of learning and communication in which students express their feelings, thoughts, and ideas about things that interest them. Students may write to think about their thoughts before sharing them with others, depending on the goal of their writing. When students' journal writing isn't graded, they can write freely without worrying about their grades" [15] Journal writing, in its different forms, is a way through which one can record personal thoughts, interests, and daily experiences. It includes written communication between the writer and him or herself, another person, or even a fictional character [16]. This interaction may be used to help learners to communicate with others by exchanging thoughts and ideas, asking for assistance, or negotiating context for oneself on paper [17].

Journals are classified by [18] into six categories; personal journals, dialogue journals, reading logs, learning logs, double-entry journals and simulated journals. [19] describes some other types of journals: dream book, autobiographies and life stories, spiritual journal, theory $\log$ and electronic journal. [20] and This tle [21] also introduce another classification of journal writing which includes personal journals/diaries, dialogue journals, double-entry journals, learning logs and response journals/reading journals.

The kind of journal writing this paper adopts is response journals/reader journals. [22] States that response journal is one of the various activities and techniques that have been used to implement the Reader Response Approach in literature classrooms. Although the primary benefit of reader response approach is developing or improving reading comprehension, the researcher thinks that response journals may be effective tools in developing and improving writing performance specially writing content and vocabulary choice.

In a reader/literature response journal, learners can respond to a literature work by recording their feelings, thoughts, responses, and questions about situations, ideas, actions, characters, settings, symbols, plots, themes, and any other elements related to that work. Learners write about things they like and things they don't like, what seems confusing or unusual to them. They analyse the events and the characters according to their understanding, make predictions about what will happen next and make a connection between their personal lives and the lives of the characters in the story. They also can relate their personal experiences to the events that happened throughout the story.

(www.busyteacherscafe.com/literacy/readers_response.ht $\mathrm{ml})$.

\section{Methodology}

\section{Statement of the Problem}

Because writing is one of the most important skills to help students communicate well in English, it needs to be developed and enhanced. It has been noted by the researcher that students in the first year secondary have low motivation and inability to write in English. And this was also supported by literature reviews [23]; [24]; [25]; [26]; [27] and also in some Arab studies [28]; [29]; [30]; [31]; [32]; [33]; [34]; [35] ; [36] that ascertained the poor performance of students in writing in English.

Therefore, the present paper attempts to investigate the effectiveness of literature response journal writing in developing English writing content and vocabulary choice among first year secondary students. Accordingly, the research problem can be stated in the following two main questions:

1- To what extent will literature response journal writing improve students' English writing content?

2- To what extent will literature response journal writing improve students' English vocabulary choice?

\section{Research Hypotheses}

The following hypotheses have been formulated to test the research problem.

1. No statistically significant mean difference will be found between the experimental and control group on writing content.

2. No statistically significant mean difference will be found between the experimental and control group on writing vocabulary choice. 
3. No statistically significant mean difference will be found between the experimental group pre and post-test on writing content.

4. No statistically significant mean difference will be found between the experimental group pre and post-test on writing vocabulary.

5.

\section{Significance of Study}

The benefit of this research is comprehensive to all levels in the teaching-learning process including learners, teachers, future researchers and curriculum designers. As for the learners, they can use literature response journal writing as an additional writing activity to improve their writing skills (Hiew, 2010). It allows them to write freely and daily in response to the literature material taught in the classroom. Regarding teachers, using literature response journal writing may help and enable English teachers to provide students with creative and engaging writing activities to practise writing on a daily basis rather than strictly adhering to the syllabus guidelines pertaining to the types of essays students study.

Considering future researchers, they may have the opportunity to pay their attention to the different kinds of journal writing and take them into their consideration to help students develop their performance in writing in English. Concerning curriculum designers, this research may help curriculum designers to design and tailor different activities using Reader Response Approach in general and Literature Response Journal writing in particular regarding writing skill into EFL syllabus to be involved in students' books and recommended in teacher's guide.

\section{Delimitation of the Study}

This paper is limited to the following:

1- First year secondary students.

2- Some EFL writing skills: content, vocabulary choice required for first year secondary school students.

3- Using Literature Response Journal writing with "Oliver Twist" by Charles Dickens which is the story students study in first year secondary.

\section{The Literature Response Journal Writing Program}

The literature response journal writing program was developed by the researcher on the basis of analyzing the writing activities in the student's book, workbook and the teacher's guide. Through these activities, students are required to write descriptive, expository, narrative and email writing. The program is based on students' responses to the literature material that was taught to them in the classroom which is the story of "Oliver Twist" by Charles Dickens. Students expressed their understanding, feelings, thoughts, reactions and questions about situations, ideas, actions, characters, settings, symbols, plots, themes, and any other elements in the story. Then, the teacher commented on their writings and the students responded again to the teacher's comments.

\section{Objectives of the program}

By the end of the program, students are expected to write correct English paragraphs which include the skills of content and vocabulary choice in three writing genres; descriptive, expository and narrative.

\section{Description of the program}

The program consists of two main parts:

- Orientation sessions

- Writing and responding sessions

\section{Orientation Sessions}

To help students to understand and to be familiar with the program they would participate in, the teacher (researcher) held three teaching and training sessions to introduce the program to them and to encourage them to participate positively in it. This training began with explaining and providing students with the ideas and assumptions of journal writing in general as a kind of reflective writing and the Literature Response Journal Writing in particular. Then, the teacher (researcher) referred to the literature material to be used in the program which is the reader included in the first year secondary syllabus, "Oliver Twist" by Charles Dickens. The students identified the author of the story, the setting, different themes and the characters in the story.

Next, students were given handouts including definitions of journal writing in general and literature response journal writing in particular. The handouts also included theoretical background of the story of "Oliver Twist", teacher's writing as a model, reader's response journal writing starters, and reader's response journal prompts. Moreover, the handouts included guidelines for each stage and step of writing. Students also received proposed worksheets to write their responses in. Then, there was a discussion between the teacher and the students concerning the teacher's model and the handouts. Finally, students were asked to write utilizing the teacher's model as a guide for them. The teacher (researcher) explained the six main steps; summary, analysis, self-reflection/feeling, personal connection, predicting and evaluating to be used in each writing class throughout the program.

\section{Writing and Responding Sessions}

After finishing the three orientation sessions, students were required to use the literature response journal writing steps to write their responses to the part they studied and read in each literature class on the basis of the proposed worksheet. Utilizing the teacher's model, students wrote their responses to the story of "Oliver Twist" under the six steps of literature response journal writing. They had four chapters in the second term. Each chapter was divided into three parts. They wrote their responses to each part at the end of each literature class. They were required to write their responses once a week. They only wrote their responses to three chapters out of four chapters. They wrote twelve entries; three during the orientation sessions and nine during the experiment. 
These writing and responding sessions included three stages:

1- Students' Writings

2- Teacher's Comment/Feedback

3- Students' replies

Stage 1: Students' Writings

They included six steps:

1-Summary: Students wrote a brief summary of what they have read. They briefly told what happened in their own words.

2- Analysis: Students wrote their opinions on characters' personalities, events and situations. They wrote brief description of characters and events. They explained how the main character changed throughout the story.

3-Self-Reflection/Feeling: Students wrote their reactions to what they have read. They expressed or described their feelings about the events and the characters. They wrote about what they liked and what they disliked. They described their favorite part or the part they found interesting. They described the part that surprised them or that they found confusing.

4-Personal Connection: Students wrote about events, topics or ideas from the story that they could connect with their real life. They wrote about how the ideas in the story related to their own experiences or related to other stories they have read or watched. They explained how the story reminded them of themselves, people they knew, or of something that happened in their lives.

5-Predicting: Students wrote their predictions about what is going to happen next, what events led to the current situation and how the story is going to end.

6-Evaluating: Students wrote about an important lesson that was learned from the events of the part that they have read. They wrote the main theme/message the author is trying to get across. They also tried to write about how difficult or easy the language or the style of the writer was.

\section{Stage 2: Teacher's Comment/Feedback}

The teacher wrote his comment/feedback on the students' writings and asked questions on the part students read in order to give them another opportunity to practise writing.

\section{Stage 3: Students' Replies}

The students got back their papers and then they wrote their replies in response to the teacher's comments and wrote their answers to the teacher's questions.

\section{Time Duration of the Program}

The program lasted for 10 weeks. The first week was for the orientation sessions. Students wrote three times during the orientation sessions. The other nine weeks were for writing and responding sessions. Students wrote once a week. They wrote nine entries. Each session lasted for 45 minutes. The writing sessions were on Tuesday each week. Students wrote their entries in a separate notebook at the end of each literature class. Some students submitted their writings at the end of the class. Others completed their writings at home and submitted them on Thursday each week. The teacher gave them back their notebooks on Sunday each week after commenting and giving his feedback. Then, students wrote their replies and their answers to the teacher's comments and questions. Finally, they submitted their notebooks in the following session. This schedule continued until the end of the program.

\section{Participants of Study}

The sample for the study was taken from 1st year secondary students. Two intact classes were originally selected and assigned to two groups used as an experimental group $(\mathrm{n}=40,9$ male and 31 female students) and a control group ( $n=45,14$ male and 31 female students). Those students are 15-16 years old and have studied English for six years in the primary and three years in the preparatory schools.

\section{Instruments of the Study}

The following tools were used to collect data; two EFL writing performance tests and the rubrics for scoring them. - EFL writing performance pre-test.

-EFL writing performance post-test . (Two rubrics were prepared for scoring the tests; one for descriptive and expository writing and one for narrative writing).

\section{Design of the Study}

The quasi-experimental pre-post-test experimental-control group design was used in the study (Schumacher \& Millan, 1996).

\section{The Experiment}

The experiment started at the beginning of the second term (2017-2018). After selecting the sample randomly, the pretests were administered to the two groups. Next, the students in the experimental group began practising writing according to the steps in the program. They wrote three times during the orientation sessions in the first week. Then, they wrote their entries once a week for other nine weeks. They wrote twelve times. The program lasted ten weeks. As for the control group they wrote using the traditional method on topics which were in their textbooks and workbooks. After completing the sessions, both the experimental and the control groups were post tested.

\section{Results}

\section{Data Analysis}

The t-test for independent samples was used to find if there were significant mean differences between the mean scores of the experimental group and the control group on writing content and writing vocabulary choice. The t-test for paired samples was used to find if there were significant mean differences between the mean scores of the experimental group pre and post-test on writing content and writing vocabulary choice. 
To measure the effectiveness of the literature response journal writing program, the two groups; experimental \& control were pre-post tested using the writing performance tests. The results will be presented here in terms of the hypotheses.

Hypothesis one: No statistically significant mean difference will be found between the experimental and control group on writing content.

The t-test for independent samples was used to find if there was a significant mean difference between the mean scores of the two groups on writing content. Table (1) shows the results.

Table (1) The t-values for the experimental and control groups in the post-test on writing content

\begin{tabular}{|c|c|c|c|c|c|c|c|}
\hline Type & Group & $\mathrm{N}$ & Mean & $\begin{array}{c}\text { Std. } \\
\text { Deviation }\end{array}$ & $\mathrm{t}$ & DF & Sig. \\
\hline \multirow{2}{*}{ Descriptive } & Experimental & 40 & 8.95 & 0.74 & \multirow{2}{*}{3.530} & \multirow{2}{*}{83} & \multirow{2}{*}{.001} \\
\hline & Control & 45 & 8.24 & 1.04 & & & \\
\hline \multirow{2}{*}{ Expository } & Experimental & 40 & 8.67 & 0.72 & \multirow{2}{*}{3.232} & \multirow{2}{*}{83} & \multirow{2}{*}{.002} \\
\hline & Control & 45 & 8.20 & 0.62 & & & \\
\hline \multirow{2}{*}{ Narrative } & Experimental & 40 & 8.82 & 0.90 & \multirow{2}{*}{3.278} & \multirow{2}{*}{83} & \multirow{2}{*}{.002} \\
\hline & Control & 45 & 8.28 & 0.58 & & & \\
\hline \multirow{2}{*}{ Total } & Experimental & 40 & 26.45 & 1.64 & \multirow{2}{*}{5.296} & \multirow{2}{*}{83} & \multirow{2}{*}{.000} \\
\hline & Control & 45 & 24.73 & 1.33 & & & \\
\hline
\end{tabular}

Table (1) shows that there is a significant mean difference at 0.05 level or higher in favour of the experimental group in the post-test on writing content in the descriptive, expository and narrative writing. So, the first hypothesis was rejected.

Hypothesis two: No statistically significant mean difference will be found between the experimental and control group on writing vocabulary choice.

The t-test for independent samples was used and table (2) shows the results.

Table (2) the t-values for the experimental and control groups in the post-test on writing vocabulary

\begin{tabular}{|c|c|c|c|c|c|c|c|}
\hline Type & Group & $\mathbf{N}$ & Mean & $\begin{array}{c}\text { Std. } \\
\text { Deviation }\end{array}$ & $\mathrm{t}$ & DF & Sig. \\
\hline \multirow{2}{*}{ Descriptive } & Experimental & 40 & 8.55 & 0.50 & \multirow[t]{2}{*}{6.233} & \multirow{2}{*}{83} & \multirow{2}{*}{.000} \\
\hline & Control & 45 & 7.68 & 0.73 & & & \\
\hline \multirow{2}{*}{ Expository } & Experimental & 40 & 9.02 & 0.80 & \multirow[t]{2}{*}{3.937} & \multirow{2}{*}{83} & \multirow{2}{*}{.000} \\
\hline & Control & 45 & 8.13 & 1.21 & & & \\
\hline \multirow{2}{*}{ Narrative } & Experimental & 40 & 8.50 & 0.87 & \multirow[t]{2}{*}{5.819} & \multirow[b]{2}{*}{83} & \multirow[b]{2}{*}{.000 } \\
\hline & Control & 45 & 7.40 & 0.86 & & & \\
\hline \multirow[b]{2}{*}{ Total } & Experimental & 40 & 26.07 & 1.59 & \multirow[b]{2}{*}{6.744} & \multirow[b]{2}{*}{83} & \multirow[b]{2}{*}{.000 } \\
\hline & Control & 45 & 23.22 & 2.21 & & & \\
\hline
\end{tabular}

Table (2) shows that there is a significant mean difference at 0.05 level or higher in favour of the experimental group in the post-test on writing vocabulary choice in the descriptive, expository and narrative writing. So, the second hypothesis was rejected

Hypothesis three: No statistically significant mean difference will be found between the experimental group pre and post-test on writing content.

The t-test for paired samples was used to find if there were significant mean differences between the mean scores of the experimental group pre and post-test on writing content. Table (3) shows the results.

Table (3) the t-values for the experimental group in the pre and post-test on writing content

\begin{tabular}{|c|c|c|c|c|c|c|c|}
\hline Type & Measures & $\mathbf{N}$ & Mean & $\begin{array}{c}\text { Std. } \\
\text { Deviation }\end{array}$ & $t$ & DF & Sig. \\
\hline \multirow[b]{2}{*}{ Descriptive } & Pre- & \multirow[b]{2}{*}{40} & 8.17 & 1.00 & \multirow[b]{2}{*}{7.429} & \multirow[b]{2}{*}{39} & \multirow[b]{2}{*}{.000} \\
\hline & Post & & 8.95 & 0.74 & & & \\
\hline \multirow{2}{*}{ Expository } & Pre- & \multirow{2}{*}{40} & 7.75 & 1.17 & \multirow{2}{*}{$\varepsilon, \Gamma \wedge T$} & \multirow{2}{*}{39} & \multirow{2}{*}{.000 } \\
\hline & Post & & 8.67 & 0.72 & & & \\
\hline \multirow{2}{*}{ Narrative } & Pre- & \multirow{2}{*}{40} & 8.05 & 1.28 & \multirow{2}{*}{$0 . T N Y$} & \multirow{2}{*}{39} & \multirow{2}{*}{.000 } \\
\hline & Post & & 8.82 & 0.90 & & & \\
\hline \multirow{2}{*}{ Total } & Pre- & \multirow{2}{*}{40} & 23.97 & 3.14 & \multirow{2}{*}{7.369} & \multirow{2}{*}{39} & \multirow{2}{*}{.000 } \\
\hline & Post & & 26.45 & 1.64 & & & \\
\hline
\end{tabular}

Table (3) shows that there is a significant mean difference at 0.05level or higher between the experimental group pre and post-test on writing content in the descriptive, expository and narrative writing in favour of the post-test. So, the third hypothesis was rejected.

Hypothesis four: No statistically significant mean difference will be found between the experimental group pre and post-test on writing vocabulary choice.

The t-test for paired samples was used to find if there were significant mean differences between the mean scores of the experimental group pre and post-test on writing vocabulary choice. Table (4) shows the results. 
Table (4) The t-values for the experimental group in the pre and post-test on writing vocabulary

\begin{tabular}{|c|c|c|c|c|c|c|c|}
\hline Type & Measures & $\mathbf{N}$ & Mean & $\begin{array}{c}\text { Std. } \\
\text { Deviation }\end{array}$ & $\mathbf{t}$ & DF & Sig. \\
\hline \multirow{2}{*}{ Descriptive } & Pre- & \multirow{2}{*}{40} & 7.40 & 1.08 & \multirow{2}{*}{8.145} & \multirow{2}{*}{39} & \multirow{2}{*}{.000} \\
\hline & Post & & 8.55 & 0.50 & & & \\
\hline \multirow{2}{*}{ Expository } & Pre- & \multirow{2}{*}{40} & 7.92 & 1.40 & \multirow{2}{*}{7.282} & \multirow{2}{*}{39} & \multirow{2}{*}{.000} \\
\hline & Post & & 9.02 & 0.80 & & & \\
\hline \multirow{2}{*}{ Narrative } & Pre- & \multirow{2}{*}{40} & 7.52 & 0.55 & \multirow{2}{*}{6.168} & \multirow{2}{*}{39} & \multirow{2}{*}{.000} \\
\hline & Post & & 8.50 & 0.87 & & & \\
\hline \multirow{3}{*}{ Total } & Pre- & \multirow{3}{*}{40} & 22.85 & 2.40 & \multirow{3}{*}{13.984} & \multirow{3}{*}{39} & \multirow{3}{*}{.000} \\
\hline & & & & & & & \\
\hline & Post & & 26.07 & 1.59 & & & \\
\hline
\end{tabular}

Table (4) shows that there is a significant mean difference at 0.05level or higher between the experimental group pre and post-test on writing vocabulary choice in the descriptive, expository and narrative writing in favor of the post-test. So, the fourth hypothesis was rejected

\section{Discussion}

The results will be discussed here in light of the two dependent variables of the study: writing content and writing vocabulary choice.

(A) Content: There was a significant difference in the gained score of the post-test on content between the experimental and control group in favor of the experimental group. It also showed that there was a significant difference in the gained score of the pre and post-test on content in the experimental group in favor of the post-test. This means that the students who used the literature response journal writing program achieved higher than the students who used the traditional way in writing. The response journal students also achieved higher in the post-test than in the pre-test.

Figures (1) and (2) show the improvement achieved.

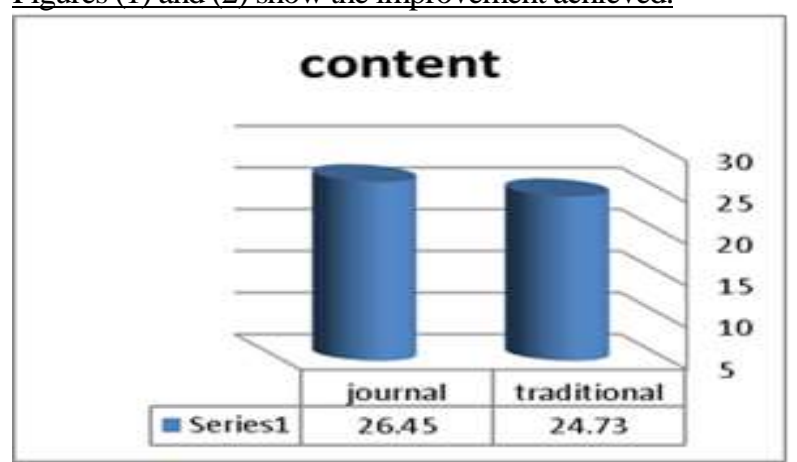

Figure (1): Achievement of the two groups on content (posttest)

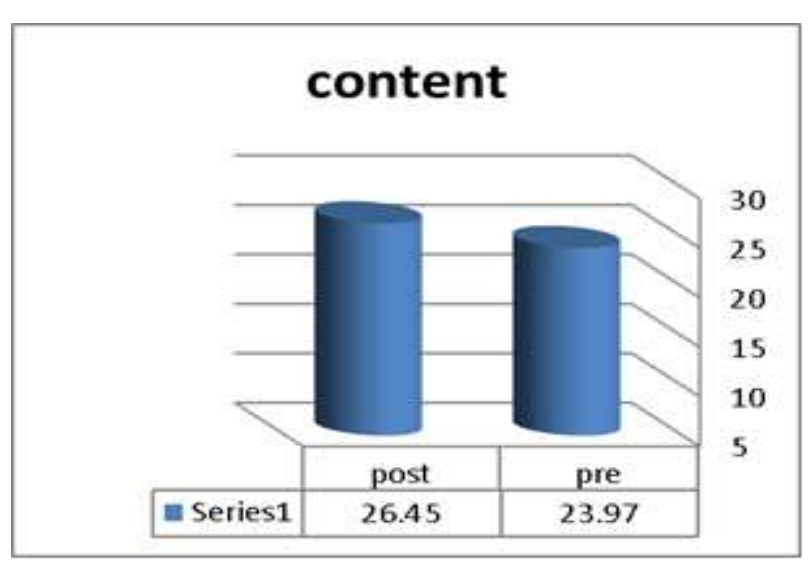

Figure (2): Achievement of the journal group in the pre-post-test

This result is probably the effect of the nature of the program in which students wrote using journal writing. It agrees with the studies of Kose (2005), Peng (2007), Salem (2007), Hiew (2010), Wafa, Syafei \& Riyono (2010), Foroutan, Noordin, and Hamzah (2013), and Dabbagh (2017) which proved that using journal writing succeeded in developing content in students' writing. They found a significant effect of journal writing on the content quality of learners' writing performance.

Other investigations have reported on the explanation for the improvement in writing performance in terms of content through the use of journal writing. Journal writing, according to Peyton and Reed (1990), is a unique sort of written interaction between two students or a student and a teacher. As pupils change their focus from the sentence level to the content level, it is a communicative mode of interaction. Meaning is more important for both writers and audience than grammatical mistakes. The goal of journal writing is to express meaning without being worried about the form. This may cause less experienced writers to concentrate more on developing the ideas they want to convey.

Journal writing, according to Fuhler (1994), allows students more flexibility of expression than typical writing tasks. Because teachers do not mark journal entries, students are more relaxed when they write. This allows them to express themselves in a non-threatening environment without fear of losing points from their overall course mark. As a result, writers of varying writing abilities can freely express themselves, knowing that they will receive feedback from their teacher. Furthermore, journal writing may provide L2 students the confidence they need to write. Exchanging dialogues through journal writing, according to Killion (1999), allows students to analyze and frame their thoughts more precisely, as well as check their opposing views before passing them on to their partners or teacher.

(B)Vocabulary Choice: There was a significant difference in the gained score of the post-test on vocabulary choice between the experimental and control group in favor of the experimental group. It also showed that there was a significant difference in the gained score of the pre- and post-test on vocabulary choice in the experimental group in favor of the post-test . This means 
that the students who used the literature response journal writing program achieved higher than the students who used the traditional writing. The response journal students also achieved higher in the post-test than in the pre-test.

Figures (3) and (4) show the improvement achieved.

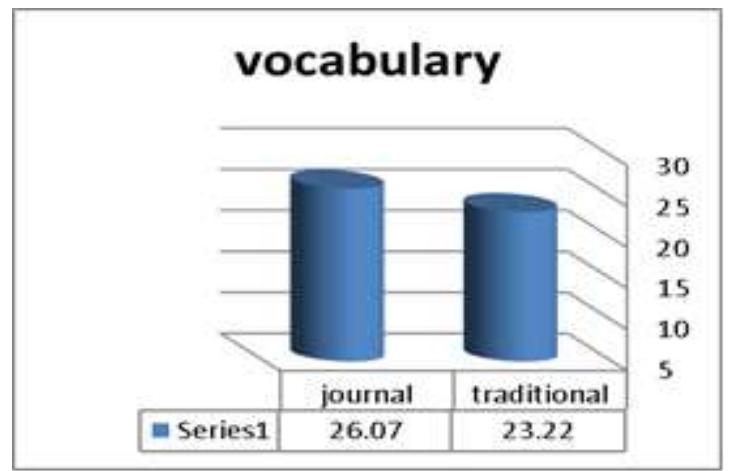

Figure (3): Achievement of the two groups on vocabulary (posttest)

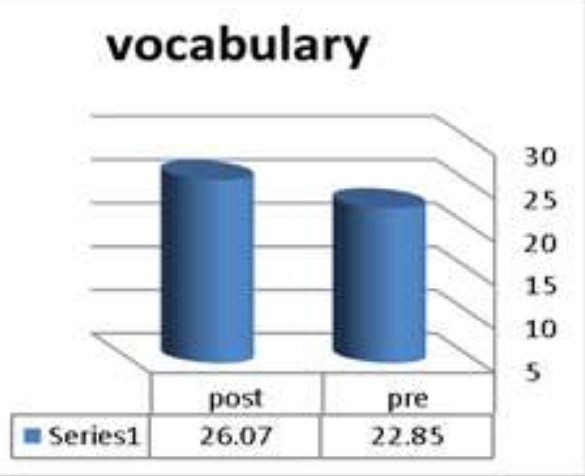

Figure (4): Achievement of the journal group in the pre-post-test

This improvement may be the result of the nature of the program in which students wrote their responses to what they have read on a regular basis. This helped them to acquire new vocabulary and new expressions. They were able to build their vocabulary. In addition, as the feedback provided by the teacher to the students' journals focused more on the appropriateness of vocabulary rather than grammatical errors, students may become aware of their lexical errors and problems and avoid repeating them in their future writings. This result agrees with the studies of Baskin (1994), Hiew (2010), Huang (2010), Wafa, Syafei \& Riyono (2010), Tuan (2010), Barjesteh, Vaseghi and Gholami (2011), Safitri (2011), Farrah (2012), Foroutan, Noordin, and Hamzah (2013) Taqil, Akbarl, Al-Nouh1, and Dashti1 (2015), Dabbagh (2017) which proved that using journal writing succeeded in developing vocabulary choice in students' writings.

\section{Conclusion}

The results obtained revealed that the literature response journal writing program proved to be effective in developing the experimental group's writing skills; content and vocabulary choice. Writing in response to literature was a new and challenging experience for students to freely express their opinions and feelings about what they have read in the story they study. It also helped them to develop new words and ideas. As for weak students, the program motivated them to write because it helped them to write with no fear of grading or correction. Therefore, it can be concluded that the literature response journal writing program proved to be an effective program in developing EFL students' writing performance.

\section{References}

[1] Abdel-Hack, I. M. (2002).The effectiveness of a task-based learning approach on EFL students' writing production. Occasional papers in the Language Education Center for Developing of English Language Teaching "CDELT", no.34, 193231.

[2] Adas, D. \& Bakir, A. (2013).Writing Difficulties and New Solutions: Blended Learning as an Approach to Improve Writing, International Journal of Humanities and Social Science, Vol.3, No.9.

[3] Akbarl, R., Al-Nouh1, N. \& Dashti1, A, Taqil, H. (2015).The Effect of Diary Writing on EFL Students' Writing and Language Abilities. British Journal of Education, Vol.3, No.2, pp. 75-91.

[4] Amer, A. (2003). Teaching EFL/ESL Literature, the Reading Matrix, vol.3.No.2.

[5] Anwar, Iman Zaki (2000).The effect of using peer review groups in Teaching essay writing to fourth year English majors, Faculty of Education, on their writing performance, apprehension, revising and attitudes. Journal of Research in Education and Psychology (Issued by: faculty of Education, Minia University), 14(1), 94-129.

[6] Barjesteh, H.; Vaseghi, R. \& Gholami, R. (2011). The effect of diary writing on EFL college students' writing improvement and attitudes. International Conference on Languages, Literature and Linguistics IPEDR, 26, 143-147.

[7] Bitchener, J. (2008). Evidence in support of written corrective feedback. Journal of Second Language Writing. 17, 102-118.

[8] Calkins (cited in Benischek, D.,Vejr, M.J. and Wetzel, S. (2001), "Improving Written Language Skills in the Primary Grades."

[9] Dabbagh, Ali. (2017). The Effect of Dialogue Journal Writing on EFL Learners' Descriptive Writing Performance: A Quantitative Study. International Journal of Applied Linguistics \& English Literature ISSN 2200-3592 (Print), ISSN 2200-3452 (Online)Vol. 6 No. 3; May 2017.

[10] Eldreeny, M. (2012). The Effectiveness of Reflective Writing in Developing EFL Writing 
Proficiency among Secondary School Students, Tanta University, Faculty of Education.

[11] Farrah, M. (2012). Reflective Journal Writing as an Effective Technique in the Writing Process. An Najah Univ. J. Res. (Humanities), Vol.26 (4).

[12] Flynn, Naomi and Stainthorp, Rhona. (2006).The Learning and Teaching of Reading and Writing. West Sussex: John Wiley \& Sons Ltd.

[13] Foroutan, M., Noordin, N., \& Gani bin Hamzah, M.S. (2013b). How can Dialogue Journal Writing improve learners' writing performance in the English as a Second Language context?

[14] IOSR Journal of Humanities and Social Science (IOSR-JHSS)e-ISSN: 2279-0837, p-ISSN: 2279 0845. Volume 7, Issue 2 (Jan. - Feb. 2013), PP 35-42 www.Iosrjournals.Org

[15] Fuhler, C. J. (1994). Response journals: Just one more time with feeling. Journal of Reading, 37, (5), 400-405.

[16] Glazier, T.F. ( The Least You Should Know about English Writing Skills .USA: Harcourt Brace College Publishers.

[17] Hamp-Lyons, L. \& Heasly, B. (2006). StudyWriting(2ndEd.).Cambridge: $\quad$ Cambridge University Press.

[18] Harmer, J. (1992).The Practice of English Language Teaching. London:Longman.

[19] Hedge, T. (1991).Writing. Hong Kong: Oxford University Press.

[20] Hiew, Wendy. (2010).The Effectiveness of Using Literature Response Journal to Improve Students' Writing Fluency. International Refereed Research Journal www.researchersworld.com Vol. - I, Issue-1.

[21] Hiemstra, R. (2001).Uses and benefits of journal writing. New Directions for adult and Continuing Education, 90, 19-26.

[22] Huang, J. A. (2010). A case study of the influence of free writing on writing fluency and Confidence of EFL college-level students. Second Language Studies, 28(2), 97-134.

[23] Killion, J. Journaling. National Staff Development Council, Journal of Staff Development, Summer, 20(3), 1999, 36-37.

[24] Kose, E. (2005). Impact of Dialog Journals on Language Anxiety and Classroom Affect. Unpublished Master's University, Thesis.Bilkent Ankara, Turkey.

[25] Meyers, A. (2005). Gateways to Academic Writing: Effective Sentences ,Paragraphs, and Essays. New York: Pearson Education, Inc.

[26] Ningrum, V., Rita, F. \& Hastini (2013). E-Journal of English Language Teaching Society (ELTS), 1 (1), $1-13$.

[27] Nunan, D. (1999). Second English Teaching and Learning .Boston: Heinle Heinle Publishers.

[28] Okasha, M. A., \& Hamdi, S. A. (2014). Using Strategic Writing Techniques for Promoting EFL
Writing Skills and Attitudes. Journal of Language Teaching \& Research, 5(3), pp. 674-681.

[29] Peng, C.Y. (2007). The Effect of Online Journal Writing on Writing Performance and Writing Selfefficiency of Undergraduate Students. Unpublished Master's Thesis. Chaoyang University of Technology, Taichung, Taiwan.

[30] Rasinski, T. \& Padak, N. (1996). Holistic reading strategies: Teaching children who find reading difficult. Englewood Cliffs, N.J.: Merrill/Prentice Hall, pg. 152-154.

[31] Safitri, Y. (2011). The effect of using diary on the eighth grade students' achievement in writing a recount text at SMPN 2 BANGIL. PHD Thesis. Jember University.

[32] Salem, M. (2007). 'The Effect of Journal Writing on Writing Performance, Writing Apprehension and Attitudes of Egyptian English Majors', 25-26.

[33] Thistlethwaite, L.L. (2000). Literacy resource series: Book E: Writing Strategies. Central Illinois Adult Education Service Center (CIAESC), pg. 49-52.

[34] Tuan, L. T. (2010).Enhancing EFL learners' writing skill via journal writing. English Language Teaching, $3(3)$, 81-88, Canadian Center of Science and Education, 81

[35] Uusen, A. (2006).Writing Skills of 1st and 2nd stage students, Faculty of Educational Sciences, Tallinn University, Estonia

[36] Wafa, A., Syafei, M., \& Riyono, A. (2010). Keeping journal writing to improve the writing ability of the tenth grade students of SMA N1 Jekulo Kudus in the academic year 2009/2010. ISSN: 1979-6889.

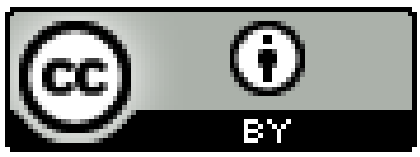

